\title{
風力発電設備支持物構造設計指針の策定 Guidelines for Design of Wind Turbine Support Structures
}

石原 孟*1

Takeshi ISHIHARA Hiroshi KATSUCHI
嶋田健司*3

土谷 学*4

Kenji SHIMADA Manabu TSUCHIYA

\section{1. はじめに}

近年, 地球温暖化をはじめとする地球環境問題に対 する関心が国際的に高まる中，発電時に二酸化炭素を 一切排出しない風力発電が注目されている。わが国の 風力発電導入量は, 新エネルギー等事業者支援対策事 業等により 1990 年代後半から急速に増加しており, 2007 年 3 月末時点で導入された風力発電設備容量は 149 万 $\mathrm{kW}$ に達し, 1314 基の風車が全国各地に建設さ れている。その一方で, 日本特有の自然環境及び地形 条件に起因する強風により，Fig. 1 及び Table 1 に示す ような風車タワーの座屈や基礎の崩壊等の重大事故も 報告されている1)，2)。

風力発電量は風速の 3 乗かつブレード長さの 2 乗に 比例することから, より高い効率を求め, 風車の大型 化が進められてきた。現在国内に設置されている大型 風車は, 翼の先端までの高さが $120 \mathrm{~m} に も$ 達している。 風力発電設備は風況の上い地点に建設されることから， 台風時にも周辺地域より強い風を受けることが多い。 また風車はヨー制御やピッチ制御と呼ばれる制御方式 が採用されており，制御によって暴風時の風車の姿勢 や作用する風荷重が異なるが，台風時の停電により制 御用電源が㲋失した場合, 風車に作用する風荷重は制 御が可能な場合に比べ大きく増大する。そのうえ，建 設地点の地形や自然環境条件は多岐にわたり, 風車本 体を支える支持物の安全性はこれらの影響を大きく受 ける。

これまでの風力発電設備支持物の構造設計では, 海 外で作成された規格や基準類をそのまま適用したもの, あるいは既存の土木, 建築, 機械等の分野の設計指針 をそのまま用いたものが多い。しかし，これらの基準 や指針は，わが国特有の自然環境条件あるいは風力発 電設備固有の特性を十分に考慮しているとは言えず， わが国に適した風力発電設備支持物構造設計指針の策
定が強く望まれてきた。

このような状況に鑑み, 平成 16 年 9 月, 土木学会 に「風力発電設備耐風設計小委員会」が設置され, 風 車の導入と建設を担当する電力会社, 風力発電事業者, 建設会社の赛務者, 風車の製造・販売を行う国内メー カーと代理店の技術者, そして大学・研究機関の研究 者からなる 35 名の委員が 3 年間の活動を経て,「風力 発電設備支持物構造設計指針・同解説」を策定し, 平 成 19 年 11 月 27 日に土木学会から刊行された ${ }^{3)}$ 。本 稿は, 風力発電設備支持物構造設計指針における耐風 設計の考え方及びその評価手法について紹介する。

\section{2. 風力発電設備の特徽と考虚すべき風荷直}

風力発電設備は風力発電機（ブレード, ハブ, ナセ ル）およびそれを支える支持物（タワー, ペデスタル， 基䊙）から構成される。また風力発電設備支持物に作 用する風荷重は, 風車タワー, ロータ及びナセルに作 用する風荷重からなるが，中でも風車ロータに作用す

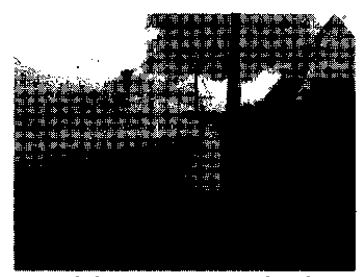

(a) タワーの倒壊

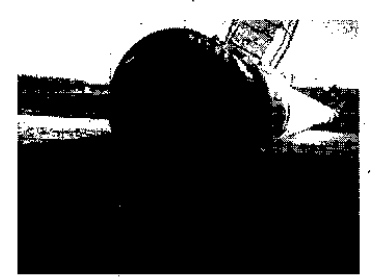

（b）基䊙の破壊
Fig. 1 風力発電設備支持物の台風被害の一例

Table 1 風力発電設備支持物の主な台風被害

\begin{tabular}{|c|c|c|c|}
\hline & & & \\
\hline 1999 & |鹿兒島県 & $250 \mathrm{~kW}$ & |タワー倒壊 \\
\hline 2002 & 沖縄県 & $250 \mathrm{~kW}$ & 基磉崩壊 \\
\hline \multirow[t]{2}{*}{2003} & \multirow[t]{2}{*}{ 沖縄県 } & $400 \mathrm{~kW}$ & タワー倒壊 \\
\hline & & $500 \mathrm{~kW}$ & 基嶘崩壊 \\
\hline 2004 & 高知県 & $750 \mathrm{~kW}$ & 基碴亀裂 \\
\hline
\end{tabular}

*1 東京大学大学院工学系研究科, 教授 Professor, University of Tokyo

*2 横浜国立大学大学院工学研究院, 准教授 Associate Professor, Yokohama National University

*3 清水建設技術研究所総合解析技術センター, 主任研究員 Senior Research Engineer, Shimizu Corporation

*4 鹿島建設環境本部新エネルギーグループ, 課長 Manager, Kajima Corporation 
る風荷重は風車の運転状況に応じて大きく変化する。

風力発電設備支持物の耐風設計を行う際には以下に 示す風力発電設備の特徴を考慮する必要がある。

1）風力発電設備は一般に風況のよい地点に設置され, 台風時には周辺地域より強い風が吹くことが多い。 設置地点での設計風速の過小評価による被害例が 見られたことから, 設置地点の自然環境条件に十 分に注意する必要がある。

2）風力発電機はヨー制御やピッチ制御と呼ばれる制 御方式が採用されており, 制御によって暴風時の 風力発電設備の姿勢や作用する風荷重が異なる。 また台風時の停電により制御用電源が喪失し, 風 力発電設備に作用する風荷重は制御が可能な場合 に比べ大きく増大する可能性がある。

3）風力発電設備は構造減衰が小さく, 振動特性は建 築物や煙突などの工作物と異なる。

4）地震が発生する時に発電している確率が高く, 地 震荷重を評価する際には発電時の風荷重を考慮す る必要がある。

また風力発電設備支持物の耐風設計を行う際には暴 風時の風荷重に加え, 発電時の風荷重も評価する必要 がある。Table 2 には風力発電設備支持物構造設計に 必要な風荷重の一覧を示す。風力発電設備支持物に作 用する長期荷重を評価する際には, 固定荷重, 積載荷 重に加え, 発電時の 10 分間平均風荷重の最大値を考 慮する必要がある。また地震が発生する時に風車が発 電している確率が高いことから，地震荷重を評価する 際には発電時の年平均風荷重を加える必要がある。更 に発電時の風荷重のピーク值は, 暴風時の風荷重と共 に，短期荷重の一つとして評価する必要がある。

Table 2 風車支持物構造設計に必要な風荷重の一覧

\begin{tabular}{|c|c|c|}
\hline 荷重の種類 & 荷重特性 & 評価対象 \\
\hline \multirow{2}{*}{ 発電時の平均風荷重 } & 10 分平均最大值 & 長期荷重 \\
\cline { 2 - 3 } & 年平均值 & $\begin{array}{c}\text { 地震荷重との } \\
\text { 組み合わせ }\end{array}$ \\
\hline 発電時の最大風荷重 & ピーク值 & 短期荷重 \\
\hline 暴風時の風荷重 & ピーク値 & 短期荷重 \\
\hline
\end{tabular}

なお，風力発電設備支持物に作用するせん断力と曲 げモーメントは高さによって支配的な風荷重が変化す ることに注意を有する。また風車タワーの共振風速は 発電時の風速範囲に入っているものの, ブレードの存 在によりタワーから発生する渦が乱されるため, 発電 時および暴風時には風車タワーの渦励振の影響が小さ いものとし, 準定常理論により風力発電設備に作用す
る風および風直交方向の風荷重を求める。

\section{3. 風力発電設備支持物耐風設計の概要}

「風力発電設備支持物構造設計指針・同解説」は, 13 章から構成されている。暴風時と発電時の風荷重は, 第 3 章により求めた設計風速および第 4 章により定め た風力係数を基に, 第 5 章に示す等価静的法により算 定する。また地震時の荷重（第 6 章）は, 風力発電設 備に作用する地震荷重に発電時の年平均風荷重（第 5 章）を加算して求める。以下，風力発電設備支持物構 造設計指針における耐風設計の概要について紹介する。

\section{1 設計風速の評価}

風力発電設備支持物を設計する際には建設地点の自 然環境を考慮した設計風速を決定することが重要であ る。建設地点の地形が平坦な場合における設計風速は, 建築基準法に示寸基準風速（10 分間平均風速の 50 年 再現期待值）を用いて，地表面粗度，八ブ高さを考慮 して評価することができる。一方, 建設地点の地形が 急峻な場合には設計風速を求めることが容易ではない。 指針では地形による平均風速の割増係数を数值流体解 析により求め, 山岳地帯における設計風速を評価した。

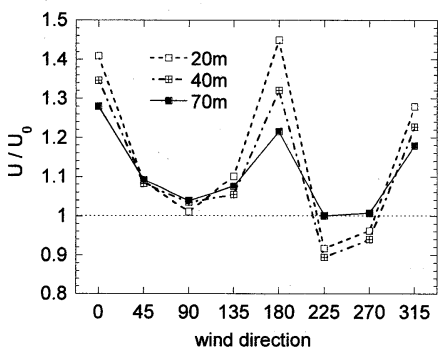

Fig. 2 複雑地形上の風速の割増係数の解析例 4)

Fig. 2 には数值解析により複雑地形上の風速の割増 係数を求めた一例を示す。このケースでは $70 \mathrm{~m}$ の高さ でも風速の割増係数が 1.2 を超えていることが分かる。 風圧力は風速の 2 乗に比例することから, 風速の割増 係数を正確に評価することは風力発電設備の耐風安全 性を考える上で極めて重要である。風車は風況のよい 地点に建設され, 台風時には周辺地域よりも強い風が 吹くことが多い。風車を建設する際に設置地点での設 計風速の評価を誤ると，台風時に大きな被害を受ける 可能性がある。

\section{2 風力係数の評価}

風力発電設備支持物に作用寸る風荷重を評価する際 には, ブレード, ナセルおよびタワーの風力係数が必 要であるが, 一般的に, ブレードとナセルの風力係数 
の入手は困難である。指針では，風力発電設備支持物 に作用する平均風荷重を算定するためのブレード，ナ セルおよびタワーの風力係数を与えた。ブレードに関 しては実際の風車に採用されているブレードの空力デ 一タをもとに標準的なブレードモデルの風力係数を定 めた。またナセルに関しては矩形および卵形の形状を 設定し, 風洞実験によって得られた実験結果をもとに 新たに風力係数を提案した。Fig. 3 に矩形型ナセルに 作用する平均抗力係数を示している。図中には 3 種類 のナセル長さ $\left(L_{n} / H_{n}=2,2.5,3\right)$ の結果を示す。ナセル の長さにはほぼ関係なく, 平均抗力係数 $C_{n D}$ の值は一 つの式で表せることが分かる。

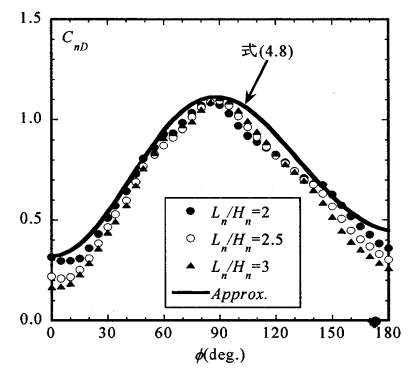

Fig. 3 矩形型ナセルに作用する平均抗力係数 5)

ナセルの平均風力係数を与える式は一様流中の風洞 実験に対して作成したものであるが，ヨー角によって 多少の差はあるものの, 平均風力係数は一様流中, 乱 流中とも同程度の大きさであるため, 最終的な評価式 はどちらもほぼ包含するものとした。

\section{3 風荷重の評価}

Table 2 に示すように風車支持物構造設計を行う際 には暴風時の風荷重に加え, 発電時の風荷重も評価す る必要がある。以下, 暴風時及び発電時の風荷重の評 価方法について示す。

\section{（a）暴風時の風荷重}

通常の構造物と異なり, 風車に作用する風荷重は風 車の姿勢によって大きく変化する。また風車に作用す る風荷重を求める際には風速の他, 風車の空気力係数, 構造諸元, 振動特性を正しく評価する必要がある ${ }^{6)}$ 。 更に暴風時における風車の姿勢は, 風車の制御方式に よって変化し, 風車に作用する最大風荷重が変化する。

Fig. 4 にはストール制御風車が風向きに正対する時 の姿勢を示す。ストール制御風車の場合にはブレード のビッチ角を制御できないため，ヨー制御を行うこと により暴風時に風車のタワーに作用する転倒モーメン トを低減している。Fig. 5 には風車のタワーに作用す
る転倒モーメントのヨー角による変化を示す。この図 からわかるように，ストール制御風車に作用寸る風荷 重はヨー角が 0 度または 180 の時に最も大きく, 90 の時に小さくなっている。

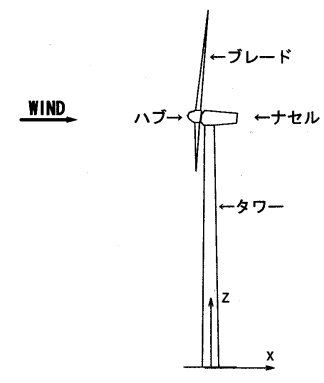

(a) 側面図

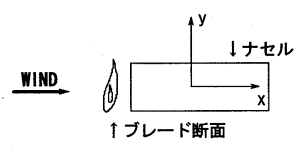

(b) 平面図
Fig. 4 ストール制御風車が風向きに正対する場合の姿勢

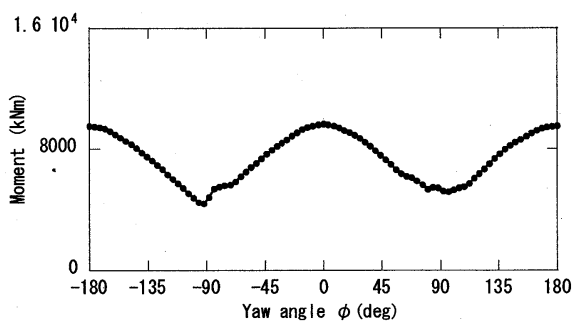

Fig. 5 タワー基部の転倒モーメントのヨー角による変化

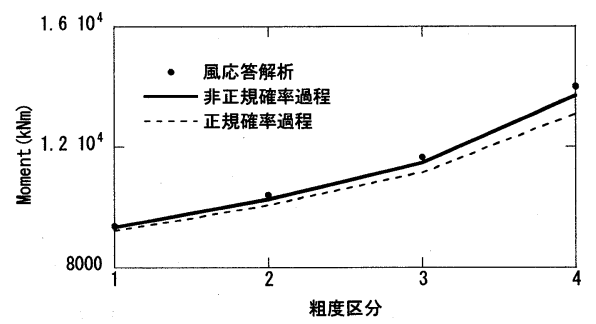

Fig. 6 タワーの転倒モーメントの乱れによる変化 ${ }^{7)}$

風力発電設備は構造減衰が小さく, 振動特性は建築 物や煙突などの工作物と異なる。また日本では山岳地 形に風力発電設備が建設されることが多く, 乱れの影 響も大きい。Fig. 6には指針で提案された評価式により 求めた粗度区分 I 〜 IVにおける風荷重と風応答解析プ ログラム $\left.{ }^{6}\right)$ から得られた風荷重との比較を示す。この 図から, 建設地点での設計風速が同じであっても, 乱 れが大きい程, 風荷重が大きいことが分かる。また指 針では，設計者に使いやすい形でガスト影響係数の簡 便式も提案した。建築基準法を模して, 粗度区分毎に おけるガスト影響係数を定めた。Fig. 7には簡便式に より求めたガスト影響係数と提案した評価式によるガ 
スト影響係数との比較結果を示す。また比較のために 建築基準法によるガス卜影響係数も併記した。建築基 準法によるガスト影響係数は風車の規模が小さい時に 過小に評価することに注意を有する。

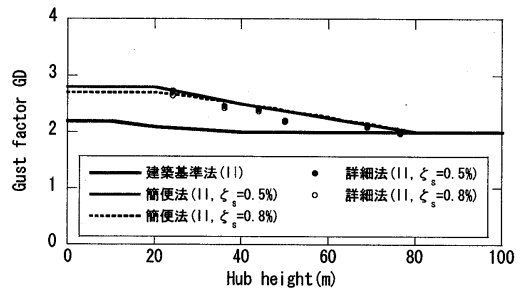

Fig. 7 ガスト影響係数のハブ高さによる変化 ${ }^{7)}$

\section{（b）発電時の風荷重}

長期荷重及び地震時に風車に作用する荷重を評価す る際には風車発電時の平均風荷重を求める必要がある。 風車発電時のロータに作用する平均風荷重はメーカー から提供されたスラスト係数により求めることができ る。ピッチ制御風車の場合には, 発電時の平均風荷重 の最大值は定格風速時に出現するのに対して, ピーク 値はカットアウト風速時に出現する場合が多いことに 注意を要する。

Fig. 8 には, $500 \mathrm{~kW}$ ピッチ制御風車の発電時にタワ 一基部における平均曲げモーメントの風速による変化 を示す。この例では風速の出現頻度はレイリー分布, 年平均風速は $8.50 \mathrm{~m} / \mathrm{s}$ と仮定している。この図から年 平均曲げモーメントに対応する風速は $7.34 \mathrm{~m} / \mathrm{s}$ であり, 年平均風速 $8.50 \mathrm{~m} / \mathrm{s}$ よりすこし低くなっていることが 分かる。

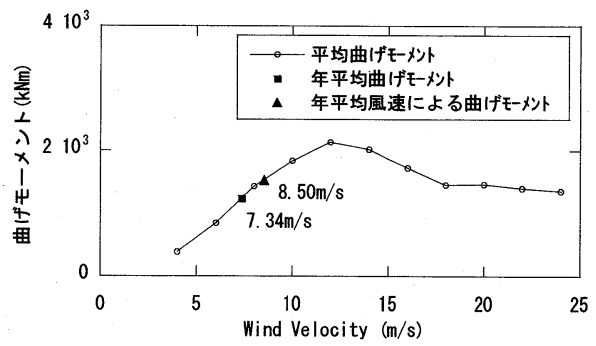

Fig. 8 タワー基部に作用する平均曲げモーメントの 風速に変化

地震が発生する時には, 風車が発電している可能性 が高いことから, 風車発電時の地震荷重には風車発電 時の風荷重の年平均値を考慮する必要がある。Fig. 9 には, 時刻歴応答解析により求めた定格出力 $400 \mathrm{~kW} の$ 風車の発電時に地震力が作用するときのタワー基部の 曲げモーメントの一例を示す。この図から, 発電時の 地震荷重の最大值は必ずしも地震力の作用方向之風向
が一致するときに出現するとは限らないことが分かる。 これは発電時の空力減衰の効果により地震荷重が低減 されることによるものである。

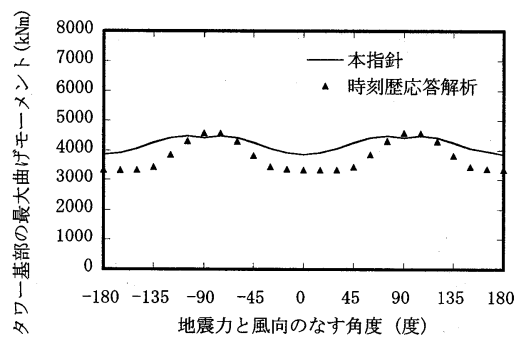

Fig. 9 タワー基部の曲げモーメントの地震力作用方 向による変化

\section{4. おわりに}

風力発電設備支持物構造設計指針に関して，その策 定の目的，耐風設計の基本的な考え方と概要を紹介し た。本指針は，風力発電設備支持物の構造設計方法を 具体的に示した国内で初めてのものであり，指針の活 用により, 風力発電設備支持物の安全性と信頼性が向 上されることを期待している。

\section{参考文献}

1）石原孟, 山口敦, 藤野陽三:2003 年台風 14 号による 風力発電設備の被害とシミュレーションによる強風の 推定, 土木学会誌, Vol.88, pp.45-48, 2003.

2) NEDO 技術開発機構:平成 16 年度風力発電利用率 向上調查委員会及び故障·事故調查分科報告書, 2005.

3）土木学会:風力発電設備支持物構造設計指針・同解 説(2007 年版), 構造工学シリーズ 17, 2007.

4）石原孟, 山口敦, 藤野陽三:複雑地形における局所 風況の数值予測と大型風洞実験による検証, 土木学 会論文集, No.731/I-63, pp.195-221，2003.

5）野田博, 嶋田健司, 石原孟:風力発電機ナセルに作 用する平均風力ならびにピーク風圧に関する研究, 第 19 回風工学シンポジウム論文集, pp.133-138, 2006.

6）石原孟, ファフックバン, 高原景滋, 銘苅壮宏: 風力 発電設備の風応答予測に関する研究, 第 19 回風工 学シンポジウム論文集, pp.175-180,2006.

7）ファフックバン, 石原孟, ビンルウンヴァン, 藤野陽三: 風力発電設備の風応答評価式の提案, 第 19 回風工 学シンポジウム論文集, pp.181-186,2006.

8）石原孟, 祝否, ルウン ヴァン ビン:風力発電設備停 止時と発電時における地震応答予測に関する研究, 第 29 回風力エネルギー利用シンポジウム,2007. 